\title{
Arms versus Democratic Allies
}

\author{
MATTHEW DIGIUSEPPE AND PAUL POAST*
}

In theory, states can gain security by acquiring internal arms or external allies. Yet the empirical literature offers mixed findings: some studies find arms and allies to be substitutes, while others find them to be complements. This article contends that these conflicting findings are due to scholars failing to consider how regime type influences the choice between arms and allies. Since democracies are highly credible allies, states that form alliances with democracies can confidently reduce their internal arms. This is not the case when states form alliances with non-democracies. This study evaluates the argument using data on military expenditures and defense pacts from 1950 to 2001. Taking steps to account for the potentially endogenous relationship between arms and allies, it finds that democratic alliances are associated with lower levels of military spending.

Keywords: alliances; military spending; domestic politics of international relations; arms versus allies.

How can states gain security? In his classic work, Hans Morgenthau offered three measures by which states can increase their relative military power and, therefore, gain security: 'they can add to their own power [through armaments], they can add to their own power the power of other nations [through alliances], or they can withhold the power of other nations from the adversary [again, through alliances]'. ${ }^{1}$ Subsequently, scholars have theorized upon and empirically evaluated the relationship between the two critical features of Morgenthau's claim - internal arms and external alliances. Though 'arms or allies or both?' is a central question to the alliance and security literatures, there has been little progress towards an answer in recent years. While much of the theoretical work expects arms and allies to serve as substitutes, ${ }^{2}$ the empirical evidence is, at best, mixed. Some find them to be substitutes. ${ }^{3}$ Others present evidence that they are complements. ${ }^{4}$

These conflicting findings are due to scholars failing to consider another critical determinant of a country's power: regime type. Democracies tend to honor alliance commitments, have a tendency to win wars, defeat long-term rivals, prevail in crisis bargaining short of war and be more selective in the wars they fight. ${ }^{5}$ Hence, democracies are both more reliable and more capable allies, and less likely to entrap alliance partners in costly conflicts. Forming a defensive alliance with a democracy means a state, assured that its ally's military resources will be effectively brought to bear against a threat, is more likely to reduce its own military spending.

* Department of Political Science, University of Mississippi (email: mrdigius@ olemiss.edu); Department of Political Science, University of Chicago (email: paulpoast@uchicago.edu). Data replication sets are available at http://dataverse.harvard.edu/dataverse/BJPolS and online appendices are available at http://dx.doi.org/ doi: $10.1017 /$ S0007123416000247.

1 Morgenthau 1948, 175.

2 Altfeld 1984; Barnett and Levy 1991; Morrow 1993; Most and Siverson 1987; Sorokin 1994.

3 Conybeare 1992, 1994; Kimball 2010; Morrow 1993; Sorokin 1994.

4 Diehl 1994; Horowitz et al. forthcoming; Morgan and Palmer 2006.

5 Bennett 1997; Bueno de Mesquita et al. 1999; Gaubatz 1996; Gibler 2008; Lai and Reiter 2000; Leeds 2003; Mattes 2012a; Reed 1997; Reiter and Stam 2002; Schultz 2001; Schultz and Weingast 2003. McGillivray and Smith (2008) attempt to bring the co-operative nature of democratic leaders and their ability to issue credible threats into a single theoretic framework. 
The democratic reliability thesis is not without its critics. The threat of leadership turnover means democracy, particularly when marked by highly fractious partisan politics, is no guarantee of ally credibility. ${ }^{6}$ It is not our goal to rectify the debates regarding democratic accountability, or to identify the exact mechanism for democratic accountability. Instead, our focus is on offering a way to address the inconsistency in the arms versus allies literature. If one accepts the premise of democratic accountability, this can help determine when allies serve as substitutes for arms and when arms are complements to allies.

Our argument has important implications for how scholars think of democracy's broader role in the international system. Since Kant in the late eighteenth century, philosophers, scholars and policy makers have viewed the expansion of democracy as offering a potentially pacifying influence. If democracies are reliable allies that induce others to reduce expenditures on internal arms, then the global march towards democracy could indeed have a stabilizing effect. This relates to NATO Deputy Secretary General Alexander Vershbow's recent remarks that helping NATO partners achieve democratic reforms enables these states to 'become producers rather than consumers of security'.

We assess our claim using data on military expenditure and defense pacts from 1950-2001. We estimate the separate effects of democratic and non-democratic alliances on national military expenditure and consider a number of confounding variables. Finding support for our claim, we then consider a three-equation empirical model that accounts for the related (and potentially endogenous) decisions to form alliances, maintain alliances and allocate financial resources towards the military. This analysis continues to find that having a democratic alliance partner is associated with lower levels of military spending in the period under investigation. Such a relationship is not associated with having a non-democratic alliance partner.

\section{THEORY}

Because the core premise of our argument is the idea that democracies are reliable allies, this section begins by explaining (and qualifying) this premise. After explaining our key premise, the section then presents our argument that states will reduce internal arms when they have democratic allies.

\section{Key Premise: The Reliability of Democratic Allies}

We base our argument on the premise that democracies are reliable allies. ${ }^{8}$ How confident can one be in this premise? On the one hand, the empirical alliance literature consistently finds that alliances between democratic states last longer, that democracies are less likely to violate the terms of their alliance agreements and that democracies are less susceptible to the termination of alliances due to swings in the leader's societal support. ${ }^{9}$ On the other hand, the theoretical basis for this claim is, at best, tenuous. Gaubatz puts forward a host of reasons for this claim, which range from domestic political constraints to democratic polities intrinsically valuing law. ${ }^{10}$

${ }^{6}$ Gartzke and Gleditsch 2004.

7 'The Myths and Benefits of Partnership with NATO.' Speech by NATO Deputy Secretary General Alexander Vershbow at Comrat University in Comrat, Moldova, 13 May 2014. Available at http://www. nato.int/ cps/bu/natohq/opinions_109808.htm, accessed 8 January 2015.

${ }^{8}$ Gibler and Wolford (2006) argue that democracy is, in part, the product of alliances: alliance eliminates conflict, which enables democracy to emerge. Even if this is the case, it will not undermine our argument, which focuses on how a state views a democracy in an alliance, not whether democracies are more or less likely to form alliances.

${ }^{9}$ Gaubatz 1996; Leeds and Savun 2007; Leeds et al. 2009.

10 Gaubatz 1996. 
Of the varied explanations, those based on domestic political constraints have received the most attention. ${ }^{11}$ According to the domestic political constraint explanation, democratic political institutions require democratic leaders to answer to public opinion. From the public's perspective, international agreements constitute a commitment, and the public desires the country to be perceived as honoring its commitments. If a leader reneges on an agreement, he or she may be perceived as untrustworthy or even incompetent. ${ }^{12}$ Both factors can compromise the leader's (and perhaps even the country's) ability to conclude future agreements. Hence, the leader risks suffering heavy domestic political costs by being voted out of office. Fearing punishment by voters, democratic political leaders are especially likely to stand by their commitments. The end result is that states recognize democracies as attractive alliance partners.

However, such 'audience costs' arguments offer a feeble explanation for the finding of democratic reliability for three reasons. First, the need to answer to a domestic audience is not unique to democracies. Some autocratic leaders, such as those in single-party dictatorships, rule only with the support of a particular audience. ${ }^{13}$ Secondly, this explanation presumes that the public as a whole supports adherence to all alliance commitments. Clare maintains that the domestic public will only punish a failure to uphold an alliance commitment if it deems the ally to be of great strategic importance. ${ }^{14}$ Thirdly, Levendusky and Horowitz further weaken the foundation of audience costs-based arguments. ${ }^{15}$ They find that leaders are commonly able to avoid the domestic punishment associated with defection by claiming that 'new information' led to the defection decision.

Given these weaknesses, Mattes clarifies the mechanism underpinning the finding of democratic reliability by emphasizing the role played by domestic institutions. ${ }^{16}$ Mattes considers two types of security co-operation agreements: defense pacts and consultation pacts. ${ }^{17}$ Defense pacts - in contrast to consultative pacts - precommit future leaders to close military cooperation with an ally. Such precommitment is critical in a democracy, where the threat of leadership turnover, particularly when marked by highly fractious partisan politics, means there is no guarantee of ally credibility. ${ }^{18}$ Precommitment devices raise the cost to the opposition of overturning a leader's policies in the interregnum. The opposition could still overturn the treaty, but this is exceedingly difficult if the defense pact was ratified through a legislative process (and, hence, became part of the country's laws). ${ }^{19}$ As Leeds et al. note, 'once a treaty becomes law, there are specific institutional procedures required for changing that law, and perhaps, negative repercussions for executives who do not adhere to established law'. ${ }^{20}$ For this reason,

${ }^{11}$ Lai and Reiter 2000; Leeds 1999; Mattes 2012a.

${ }^{12}$ Guzman 2009; Smith 1998.

${ }^{13}$ Weeks 2008.

${ }^{14}$ Clare 2013. Of course, this requires the public to recognize when a particular ally is strategically important. How the public makes such a determination is left unclear by Clare, but it would likely be a function of the leader's own statements regarding the ally.

${ }^{15}$ Levendusky and Horowitz 2012. This result is confirmed by Levy, McKoy, Poast, and Wallace 2015.

${ }^{16}$ Mattes 2012a.

17 The Alliance Treaty Obligation and Provision (ATOP) dataset has five categories of primary alliance types: defensive, offensive, consultative, neutrality and nonaggression. The latter two, neutrality and nonaggression, are not true alliance agreements because they do not call on the parties to take action if one of the parties is attacked. In the ATOP dataset, pure offensive pacts (meaning they do not also contain a defensive or consultative provision) are very rare (nine out of 648 agreements). In comparison, there are ninety-two pure defensive pacts (meaning they do not also contain an offensive or consultative provision) and 217 pure consultative pacts (meaning they do not also contain an offensive or defensive provision).

${ }^{18}$ Gartzke and Gleditsch 2004.

19 Dai 2005; Kydd 2009, 298; Martin 2000.

${ }^{20}$ Leeds et al. 2009, 462. 
Mattes argues that the link between democracy and alliance reliability should only apply to defense pacts.

Given Mattes' qualification to the democracy-alliance reliability link, leaders wishing to violate a defense pact face two domestic costs. The first are the potential audience costs stemming from public perceptions of failing to honor a state's commitments. The second, and perhaps more important costs, are those associated with deviations from moderate policy and from circumventing domestic institutions meant to constrain behavior. ${ }^{21}$ To be clear, democratic institutions do not guarantee compliance with defense pacts. In a system without a centralized enforcement mechanism, nothing can guarantee compliance. But democratic institutions at least raise the cost of defecting from a defense pact.

\section{The Argument: Democratic Allies and Internal Arms}

The idea that democracies are highly reliable defensive allies has important implications for the relationship between the two primary instruments of military power: internal arms and external alliances. By 'internal arms', we are referring to indigenous security measures that boost the relative military capabilities of a nation-state. Such measures include increasing military spending, developing technology and boosting the size of the armed forces.

The value states place on such policies is influenced by the fear of being abandoned by an ally in a crisis. Treaties are contracts, meaning they specify a set of obligations for the parties, and the conditions under which the parties are expected to fulfill those obligations. ${ }^{22}$ This applies to alliance treaties. ${ }^{23}$ But since the international system lacks a centralized mechanism for enforcing treaty contracts, states always face the risk of abandonment. ${ }^{24}$ The greater the risk of abandonment, the more a state will seek to insure itself against the risk by maintaining a stockpile of internal arms. ${ }^{25}$

As we just discussed, the risk of such abandonment varies by country. If we accept that institutional constraints make democracies inherently more reliable defensive alliance partners, the risk should be lowest when the ally is democratic. The reliability of the democracy's commitment should, in turn, make it easier for a state to substitute allies for arms. That is, forming a defensive alliance with a democracy means a state is more likely to reduce military spending.

We are not claiming that a state with a democratic ally will completely eliminate its own military expenditures. In a war, it can take time for an ally to mobilize its military resources. Hence, even if an ally provides the bulk of the military capacity, the state still requires some internal arms in order to offer resistance and buy the ally time to mobilize. Also, because there is always some risk that the ally will remain home, internal arms and the arms of an ally are not perfect substitutes. ${ }^{26}$ Nevertheless, on the margin, a reliable ally gives the state an incentive to allocate some internal resources away from security and towards other functions. ${ }^{27}$ States have an incentive to spend as little as possible on internal arms because arms are, in the words of

21 Beyond alliance politics, evidence indicates that democratic foreign policy, in terms of trade and UN General Assembly voting, remains relatively constant with leader turnover, while policies significantly change with leadership turnover in non-democratic polities (Mattes et al. 2015; McGillivray and Smith 2004).

22 Koremenos et al. 2001.

23 Leeds 2003, 805, footnote 10; Leeds et al. 2002, 239.

24 Snyder 1984.

25 Sorokin 1994.

26 Though such concerns can be partially ameliorated by the ally stationing troops on the state's territory (Morrow 1994).

27 Kimball 2010. 
Nordhaus and Tobin, 'regrettables': 'No reasonable nation purchases defense because its services are desired per se. The product of defense outlays is national security. ${ }^{28}$

To illustrate our argument, consider concerns about free-riding in alliances - the notion that weaker members of an alliance contribute less, relative to their economic output, to security than larger and wealthier members of an alliance. ${ }^{29}$ Evidence indicates that free-riding is prevalent among the members of NATO. ${ }^{30}$ As former US Defense Secretary Robert Gates remarked in at 2011 speech, 'I am the latest in a string of US defense secretaries who have urged allies privately and publicly, often with exasperation, to meet agreed-upon NATO benchmarks for defense spending., ${ }^{31}$ One could claim that free-riding within NATO is due to the security-autonomy trade-off between the members: ${ }^{32}$ the United States, as the powerful member, receives autonomy-enhancing benefits (for example, the right to establish bases on the ally's territory or economic concessions), while the smaller members gain security from the United States. However, there was little evidence to suggest that free-riding behavior existed in the Warsaw Pact, despite it also being dominated by a single powerful state (the Soviet Union). Similarly, from its formation in 1945 to the signing of the peace agreement between Israel and Egypt in 1979, the Arab League exhibited little evidence of free-riding behavior, even though Egypt's economic and military might far outstripped that of the other members. ${ }^{33}$ Our argument suggests that these findings stem from NATO, in contrast to the Warsaw Pact and Arab League, being comprised of democracies: because such allies face high costs if they abandon an ally, the smaller alliance partners in the asymmetric alliance relationship, holding all else equal, could more confidently reduce internal armaments.

Our argument implies that a potential alliance partner's regime type will influence a state's decision to internally arm. If states form a defense pact with a democracy, the democracy's reliability means the state can be confident that the ally's military resources will be used in a crisis, thereby substituting for a portion of the state's own military resources. This enables the state to reduce, though not necessarily eliminate, its own military spending. This leads to our hypotheses:

HYPOTHESIS 1: States with a defensive alliance with a democratic state will have lower military spending than those with no defensive alliances.

HYPOTHESIS 2: States with a defensive alliance with a democratic state will have lower military spending than those with defensive alliances with a non-democratic state.

Before testing the hypotheses, some qualifications are in order. If democracies are more reliable allies precisely because leaders in democracies are institutionally constrained, then democratic leaders will be cautious and selective in choosing allies. Hence, democracies should also be less likely to form alliances. Indeed, this is the finding of previous research. ${ }^{34}$ But democracies will (and have) formed alliances. Since alliance formation is a bargaining process, democracies likely drove hard bargains when negotiating the terms of the alliance. ${ }^{35}$ This can result in the

28 Nordhaus and Tobin 1972, 28.

29 Olson and Zeckhauser 1966.

30 Plumper and Neumayer 2015.

31 Robert Gates, 'The Security and Defense Agenda (Future of NATO).' Remarks delivered by Secretary of Defense Robert M. Gates, Brussels, Belgium, 10 June 2011. Available at http://www.defense.gov/ speeches/ speech.aspx?speechid=1581, accessed 8 January 2015.

32 Morrow 1991.

33 Chen et al. 1996, 328. The Arab League is ATOP alliance \# 3120.

34 Fordham and Poast Forthcoming; Gibler 2008; Gibler and Wolford 2006.

35 Benson et al. 2014; Poast 2012. 
alliance treaty granting the democracy very large autonomy benefits. ${ }^{36}$ For instance, Mattes finds that mixed-regime dyads are more likely to create alliance treaties that contain economic provisions - a clear form of autonomy-enhancing issue linkage. ${ }^{37}$ This suggests that the bargaining leading to alliance formation serves, from the democracy's perspective, to sort suitable and unsuitable potential allies. Regardless of how the sorting occurs, we must account for such a selection process in our analysis.

We should acknowledge that, while states may prefer democratic defense pacts due to their reliability, this does not mean non-democracies will be unable to find allies. This is for two reasons. First, the selectiveness of democracies could leave states with little option but to form a pact with a less reliable nondemocratic partner. Indeed, one advantage of a non-democratic state is that it may be willing to enter into a war that is expected to be costly. In contrast, extensive research suggests that democracies will avoid such conflicts, largely out of a leader's fear that voters will punish him or her (with removal from office) if the war is lost or if the war places an enormous burden (in terms of lives and money) on the population. ${ }^{38}$ Secondly, one must not downplay the importance of common foreign policy interests. While autocratic states, all things being equal, are less reliable, a state may align with a non-democracy if its foreign policy interests, namely the perceived threats, are sufficiently similar. For example, consider the views within republican France in the late 1880s of the prospects of forming an alliance with autocratic Russia. French diplomat and eventual foreign minister Théophile Declassé wrote in June 1887:

To France and Russia alike, a common peril calls imperatively for the closest co-operation [...] They will both be obliged to bring pressure of the same sort upon Germany [...] Everywhere they confront the same enemies, share the same interests, cherish the same aspirations. The astonishing thing is that an Entente of such obvious mutual advantage should have taken so long to fructify. ${ }^{39}$

Exactly how alliances with non-democracies will influence military expenditures is unclear. Our theory leads us to expect that they will definitely not decrease. However, it is not obvious that they will remain flat. If the French decision to enter an alliance with Russia in the 1890s is any indication, states might be willing to align with non-democracies when they are in a high-threat environment. Under such circumstances, states will pursue multiple avenues of defense, namely acquiring both internal arms and seeking allies. Under such circumstances, we would see states joining alliances with non-democracies and building arms.

\section{EMPIRICAL ANALYSIS}

To test our hypotheses, we adopt a country-year unit of analysis of all states with available data from $1950-2001 .^{40}$ First, using the log of military expenditures, we assess the separate effects of alliance commitments with democratic and non-democratic partners. Secondly, we consider that the decision to increase military spending and the decision to form and remain in an alliance are likely related. To demonstrate the robustness of our results to the potential bias introduced by this form of endogeneity, as well as possible bias from selection into the sample, we present

${ }^{36}$ Morrow 1991.

${ }^{37}$ Mattes 2012b; Poast 2013.

${ }^{38}$ Bueno de Mesquita et al. 2003; Hart and Reed 1999; Reiter and Stam 2002; Reiter et al. 2009.

${ }^{39}$ Quoted in Michon 1929, 20.

${ }^{40}$ We would prefer to test our hypotheses on a longer period. However, the absence of reliable economic activity data before 1950 , a primary predictor of military spending, constrains our sample. Tests excluding this important predictor would suffer from omitted variable or measurement bias. 
a three-equation, unified model that jointly estimates a state's military expenditure, probability of alliance ties with a democracy and the probability of alliance ties with a non-democratic state.

We begin this section by describing the dependent variable, explanatory variables and control variables used in our main analysis. After providing the results to our main analysis, we visually depict the substantive long-term effects, offer the results from some robustness tests, and then discuss the estimation and results from our three-equation unified model.

\section{Dependent Variable}

Our dependent variable is the level of military expenditures in country $i$ in year $t$. To capture military expenditures, we use Nordhaus et al.'s military spending data that draws on the Correlates of War and SIPRI datasets. ${ }^{41}$ These data are converted to constant dollars and adjusted for purchasing power parity (PPP). Like Nordhaus et al.'s recent study and others, we estimate the log of military expenditure and include the log of a state's GDP on the right-hand side of the equation to capture its size. ${ }^{42}$

An alternative approach is to estimate a state's military spending as a proportion of its economic output. ${ }^{43} \mathrm{We}$ are reluctant to adopt this alternative approach because a relationship between our covariates and the denominator of the dependent variable may bias our results. ${ }^{44}$ Furthermore, we believe our approach more accurately reflects the logic of the argument that concerns the amount of resources brought to an alliance, rather than the proportion of spending relative to domestic resources.

For three reasons, we include the lagged dependent variable on the right-hand side of our equation. First, the addition of the lagged value effectively estimates the change in military spending, which is closer to our theoretical interest than examining variation in levels of military expenditure. ${ }^{45}$ Secondly, we have strong theoretical reasons to believe the datagenerating process is time dependent. Military expenditures, like many government budgetary items, are slow moving and are a function of budgetary inertia. ${ }^{46}$ The lagged dependent variable addresses concerns of potential serial correlation that arise from this dynamic. Thirdly, inclusion of the lagged dependent variable allows us to estimate the long-term effect of alliance commitment on this slow-moving variable. ${ }^{47}$

\section{Primary Explanatory Variables}

To construct our primary explanatory variables, we rely on the Alliance Treaty Obligations and Provisions (ATOP) dataset and a binary indicator of regime type ${ }^{48}$ Here, we focus solely on defensive alliance commitments as indicated by ATOP. We concentrate on defensive alliances for two reasons. First, as discussed in the theory section, Mattes provides a reasonable explanation of why democracies should more reliably commit to defense pacts than autocracies. ${ }^{49}$ Secondly, while other forms of alliance commitments (offensive, neutrality, non-aggression or consultation) may also provide a reason to limit military spending, defensive

41 Nordhaus et al. 2012.

${ }^{42}$ Like related studies, we log military expenditure to address the skewed distribution.

43 Fordham and Walker 2005; Goldsmith 2007.

${ }_{44}$ However, we show in the Appendix that our results are robust to this alternative specification.

45 Boef and Keele 2008.

46 Nordhaus et al. 2012.

47 Keele and Kelly 2006.

48 Leeds et al. 2002.

49 Mattes 2012a. 
TA в L $1 \quad$ Alliances and Military Spending, Basic Patterns

\begin{tabular}{lccc}
\hline \hline & \multicolumn{2}{c}{ Military spending/GDP } \\
\cline { 2 - 4 } Variable & Obs & Mean & Std. Dev. \\
\hline All states & 5,889 & 0.045 & 0.067 \\
No defense pact & 1,529 & 0.035 & 0.04 \\
Any defense pact & 4,360 & 0.049 & 0.073 \\
Defense pact with democracy & 2,702 & 0.031 & 0.036 \\
Defense pact with non-democracy & 3,596 & 0.052 & 0.078 \\
Defense pact with democracy \& no non-democratic defense pact & 2,312 & 0.031 & 0.034 \\
Defense pact with non-democracy \& no democratic defense pact & 1,284 & 0.091 & 0.112 \\
\hline \hline
\end{tabular}

Note: 'Each of the following relationships show a statistically significant difference at the 0.99 level (two sided t-test): "No Defense Pact" and "Defense pact", "Defense pact with democracy" and "No Defense Pact", "Defense pact with democracy" and "Defense pact with non-democracy", and "Defense pact with democracy and no non-democratic defense pact" and "Defense pact with non-democracy and no democratic defense pact.",

alliance commitments are directly relevant to our purposes because they require costly action in the event of conflict. Other alliance agreements may have little bearing on a state's internal arming because they do little to reduce the costs of defense during peace or conflict. For example, an agreement to provide consultation or remain neutral does little to offset a state's internal arms. Thus pooling all alliance types may obscure the relationship we are directly interested in estimating. ${ }^{50}$ For each observation, we then include two dichotomous variables. The first indicates whether a state is on the receiving end of a defensive pact obligation with a democratic state. The second indicates receiving a similar obligation from a non-democratic state. We identify democratic alliance partners as states with a score of 7 or higher on the 21-point Polity scale. ${ }^{51} \mathrm{We}$ consider allies below this threshold to be non-democratic. ${ }^{52}$

Our initial instinct is to employ a multiplicative term indicating the effect of a defensive alliance on military spending conditional on the regime type of the alliance partner. However, this strategy is unsuitable for our purposes. First, we can only observe an alliance partner's regime type when an alliance forms. Secondly, it is possible for states to hold defensive alliances with both democratic and non-democratic states. Thus an indicator of an alliance partner's regime type will be collinear with the presence of an alliance. An interaction term will then prevent us from observing the separate effects of democratic and non-democratic alliances. Separately estimating the effects of democratic and non-democratic alliances allows us to overcome these obstacles and eases interpretation without introducing bias.

Having described our dependent variable and key independent variables, it is useful to consider some basic descriptive patterns in the data. Table 1 presents the average military spending, displayed here as a percentage of GDP, of states based on being in a defense pact and

${ }^{50}$ Diehl 1994, 164. However, we ran our central models with pooled alliance indicators, excluding non-aggression pacts, and found similar results (reported in the Appendix). This is likely driven by the significant overlap in alliance commitments.

51 Marshall et al. 2010.

52 Our results are robust for democratic thresholds below 7 on the 21-point polity score. However, the central effect is most likely driven by the most democratic states. As we illustrate in the Appendix, defense pact partner Polity scores cluster at the extremes of the Polity scale. Few states hold alliances with states between -7 and 7 on the Polity scale. 
the regime type of their defensive ally. While military expenditures as a percentage of GDP is not the most appropriate metric for our analysis, it is useful for providing an initial descriptive look at how alliance relationships influence military expenditures. We observe that states with a democratic defense pact partner have lower rates of military spending than those without a defense pact and those that have defense pacts with non-democracies.

Beyond looking at the differences between states, we also examined the changes in military spending before and after alliance formation. When aggregating all alliances irrespective of partner regime type, 37 per cent of states see a reduction in their ratio of military spending over GDP in the five years after an alliance formation. Among states that form a non-democratic alliance, 35 per cent experience a reduction in their military burden. In contrast, among states that form a defense pact with a democratic alliance partner, 53 per cent see a reduction in their military burden. This is compared with a baseline change over five years of 34 per cent for states that do not form any alliances.

While consistent with our theoretical expectations, it is important that we account for features of our data that might bias these findings. This includes the possible influence of omitted variables. Therefore, we now describe control variables before discussing and presenting our multivariate analysis.

\section{Control Variables}

As mentioned, we control for a country's wealth with the log of real GDP (adjusted for PPP). Several studies have found that democratic polities spend considerably less on security than non-democratic states, ${ }^{53}$ and that democracies are more likely to form alliances with states of similar regime types. ${ }^{54}$ Thus we include an indicator of the observed state's Polity score ${ }^{55}$ to ensure that we are not capturing the influence of a state's regime type through its choice of alliance partners. Next, we include binary variables indicating participation in an ongoing interstate or civil war to address active demands on spending. To address non-active threats, we include the logged sum of a state's rival's military expenditure. ${ }^{56} \mathrm{We}$ rely on Thompson's classification of rivals to construct this measure. ${ }^{57}$ Beyond regime type, alliances vary in their institutionalization. Moreover, it is possible that highly coordinated alliances are both more reliable and more democratic. ${ }^{58}$ As such, we control for the level of peacetime coordination to protect against finding a spurious relationship. We employ a four-value discrete measure suggested by Leeds and Anac, in which higher values indicate a higher level of peacetime military coordination. ${ }^{59}$ For states that have multiple defense pacts, our measure reflects the highest level of military coordination across all of a state's alliances. $^{60}$

${ }^{53}$ Fordham and Walker 2005; Goldsmith 2007.

${ }^{54}$ Lai and Reiter 2000.

${ }_{55}^{55}$ Marshall et al. 2010.

${ }^{56}$ In additional tests reported in the Appendix, we employ Leeds and Savun's (2007) measure of politically relevant international threat environment as an alternative measure of threat that is calculated as the summed capabilities of all politically relevant states that hold an S-score below the global median. Our central findings remain largely unchanged.

57 Thompson 2001.

58 Johnson et al. 2015; Leeds and Anac 2005.

${ }^{59}$ Leeds and Anac 2005.

${ }^{60}$ The variable is coded 3 if an alliance provides for joint troop placements or military bases; 2 if it has one of the following: official contact for military planning during peacetime, a formal military organization, at least one party is required to provide training and/or technology, the alliance includes specific plans for subordination 
тав ве 2 Alliances and Military Spending, Multivariate Analysis

\begin{tabular}{|c|c|c|c|c|c|}
\hline & $\begin{array}{l}\text { (1) } \\
\text { OLS }\end{array}$ & $\begin{array}{l}\text { (2) } \\
\text { OLS }\end{array}$ & $\begin{array}{c}\text { (3) } \\
\text { Country FE }\end{array}$ & $\begin{array}{l}\text { (4) } \\
\text { Year FE }\end{array}$ & $\begin{array}{l}\text { (5) } \\
\text { Inst. LDV }\end{array}$ \\
\hline Defense Alliance & $\begin{array}{c}0.00451 \\
(0.0106)\end{array}$ & & & & \\
\hline Defense Alliance $_{\text {Dem }}$ & & $\begin{array}{c}-0.0525^{*} \\
(0.0105)\end{array}$ & $\begin{array}{c}-0.0472 * * \\
(0.0170)\end{array}$ & $\begin{array}{c}-0.0543^{*} \\
(0.00946)\end{array}$ & $\begin{array}{c}-0.194 * \\
(0.0302)\end{array}$ \\
\hline Defense Alliance $_{\text {Nondem }}$ & & $\begin{array}{c}0.0265 * * \\
(0.00971)\end{array}$ & $\begin{array}{c}0.0587^{*} \\
(0.0177)\end{array}$ & $\begin{array}{l}0.0303 * * \\
(0.0100)\end{array}$ & $\begin{array}{c}0.131 * \\
(0.0234)\end{array}$ \\
\hline $\ln (\text { Military Exp. })_{t-1}$ & $\begin{array}{l}0.907 * \\
(0.00993)\end{array}$ & $\begin{array}{c}0.903^{*} \\
(0.0100)\end{array}$ & $\begin{array}{c}0.770 * \\
(0.0176)\end{array}$ & $\begin{array}{c}0.907 * \\
(0.00606)\end{array}$ & $\begin{array}{c}0.667 * \\
(0.0493)\end{array}$ \\
\hline Polity & $\begin{array}{c}-0.00335^{*} \\
(0.000673)\end{array}$ & $\begin{array}{c}-0.00255^{*} \\
(0.000703)\end{array}$ & $\begin{array}{c}-0.00484 * \\
(0.00129)\end{array}$ & $\begin{array}{c}-0.00186 * * \\
(0.000629)\end{array}$ & $\begin{array}{r}-0.00691 * \\
(0.00118)\end{array}$ \\
\hline $\ln$ (Rival Mil. Exp.) & $\begin{array}{c}0.00579 * \\
(0.00128)\end{array}$ & $\begin{array}{l}0.00647 * \\
(0.00129)\end{array}$ & $\begin{array}{c}0.0130 * \\
(0.00252)\end{array}$ & $\begin{array}{r}0.00558 * \\
(0.00115)\end{array}$ & $\begin{array}{c}0.0183^{*} \\
(0.00273)\end{array}$ \\
\hline Interstate War & $\begin{array}{l}0.0987 * \\
(0.0225)\end{array}$ & $\begin{array}{c}0.101 * \\
(0.0230)\end{array}$ & $\begin{array}{c}0.103 * \\
(0.0214)\end{array}$ & $\begin{array}{c}0.0970^{*} \\
(0.0212)\end{array}$ & $\begin{array}{c}0.196 * \\
(0.0356)\end{array}$ \\
\hline Civil War & $\begin{array}{c}0.0418^{*} \\
(0.0178)\end{array}$ & $\begin{array}{c}0.0380^{*} \\
(0.0181)\end{array}$ & $\begin{array}{c}0.0676^{*} \\
(0.0189)\end{array}$ & $\begin{array}{c}0.0421 * \\
(0.0179)\end{array}$ & $\begin{array}{c}0.0779 * \\
(0.0221)\end{array}$ \\
\hline $\ln (\mathrm{GDP})$ & $\begin{array}{c}0.0907^{*} \\
(0.0107)\end{array}$ & $\begin{array}{c}0.0965^{*} \\
(0.0108)\end{array}$ & $\begin{array}{c}0.203^{*} \\
(0.0189)\end{array}$ & $\begin{array}{c}0.0952 * \\
(0.00657)\end{array}$ & $\begin{array}{c}0.345^{*} \\
(0.0516)\end{array}$ \\
\hline Peacetime Coordination & $\begin{array}{c}0.0248^{*} \\
(0.00559)\end{array}$ & $\begin{array}{c}0.0244^{*} \\
(0.00566)\end{array}$ & $\begin{array}{l}0.0128 \\
(0.00730)\end{array}$ & $\begin{array}{c}0.0186^{*} \\
(0.00480)\end{array}$ & $\begin{array}{c}0.0653 * \\
(0.0116)\end{array}$ \\
\hline Constant & $\begin{array}{c}-0.330^{*} \\
(0.0578)\end{array}$ & $\begin{array}{c}-0.350 * \\
(0.0582)\end{array}$ & $\begin{array}{c}-0.406^{*} \\
(0.172)\end{array}$ & $\begin{array}{c}-0.300^{*} \\
(0.0446)\end{array}$ & $\begin{array}{c}-1.408^{*} \\
(0.221)\end{array}$ \\
\hline $\begin{array}{l}\text { AR1 } \\
\text { Observations }\end{array}$ & $\begin{array}{c}\text { Yes } \\
5.889\end{array}$ & $\begin{array}{c}\text { Yes } \\
5.889\end{array}$ & $\begin{array}{c}\text { Yes } \\
5.889\end{array}$ & $\begin{array}{r}\text { Yes } \\
5.889\end{array}$ & $\begin{array}{c}\text { No } \\
5.742\end{array}$ \\
\hline$R^{2}$ & 0.981 & 0.981 & $\begin{array}{l}5,009 \\
0.981\end{array}$ & $\begin{array}{l}J, 003 \\
0.982\end{array}$ & 0.969 \\
\hline
\end{tabular}

Note: Models 1-4: panel corrected standard errors in parentheses; Model 5: robust standard errors in parentheses. ${ }^{*} \mathrm{p}<0.05$.

\section{Multivariate Results}

Table 2 presents the results of four models estimating the log of military expenditure. In each model, except Model 4, we estimate the equations with a panel-specific autoregressive structure and report panel-corrected standard errors. These features enable us to address residual serial correlation in the errors, the potential for temporally correlated errors and dependence among the panels. ${ }^{61}$

Model 1 estimates the effect of a defense pact regardless of the partner's regime type. The coefficient is insignificant. This indicates that, in the aggregate, there is no support for the notion that a defensive alliance influences a state's military expenditure. The remaining models in Table 2 separate the effect of democratic and non-democratic defense pacts. Model 2 presents the estimates of a pooled sample, while Models 3 and 4 add country and yearly fixed effects, respectively. These models indicate that a defensive alliance with a democracy is associated with a statistically significant decline in military spending, and a defensive alliance with a

(F'note continued)

during conflict or specifies contribution levels in the event of a conflict; 1 if there are no conditions for military coordination; and 0 if it has no defensive alliances.

61 Beck and Katz 2011. 
non-democracy is associated with a significant increase in military spending. As such, the models indicate that states with defense pacts with democratic states, holding all else equal, have lower military spending than both states with no defense pacts and those that hold defense pacts with a non-democracy. This provides initial support for Hypotheses 1 and 2. Substantively, the presence of a defense pact with a democracy is associated with an approximately 5 per cent decrease in military spending. ${ }^{62}$ The persistence of the significant coefficient when including country and yearly fixed effects demonstrates that the result is robust to both unobserved unit heterogeneity and temporal dynamics that may influence the demand for military spending.

Next, consider Model 5. It is possible that the lagged dependent variable is correlated with the other covariates, which may generate biased estimates. As recommended by Nordhaus et al., we instrument the lagged dependent variable with two lags of GDP and two lags of the log of rival military spending to address this potential bias. ${ }^{63}$ As reported, the coefficient on the lagged dependent variables is much smaller. However, the Defense Alliance Dem $_{\text {coefficient remains }}$ negative, significant and suggests a much larger substantive effect: a 17.6 per cent decrease in military expenditure. ${ }^{64}$

As noted, Models 2-5 indicate that a defensive alliance with a non-democracy has a positive and significant relationship with military expenditure. Our theory only leads us to expect that non-democratic allies will not induce a decrease in expenditures. However, our theory is silent as to whether the relationship is null or positive. It might be the case that a non-democratic alliance is associated with higher spending because such alliances are more likely to form in high-threat environments. Yet the statistical significance of the coefficient persists when we control for rival capabilities and an alternative measure of threat environment (reported in the Appendix). We take up this puzzling result below following a discussion of the estimated long-run effects.

\section{Long-Term Substantive Effects}

As mentioned earlier, including the lagged dependent variable allows us to estimate the longterm effect (LTE) of our independent variables. The LTE is calculated by dividing the coefficient of the relevant regressor by one minus the coefficient of the lagged dependent variable: $L T E=\frac{\beta_{i}}{1-\gamma} .{ }^{65}$ Researchers often neglect this piece of information. However, it is especially relevant here because of the slow-moving nature of military expenditure resulting from bureaucratic inertia and the persistent nature of defense pacts.

To assess the significant and substantive long-term effects, we employ an approach recommended by Williams and Whitten that simulates several dynamic scenarios over time. ${ }^{66}$ Figure 1 presents the results of three such simulations over twenty years based on the estimates of Model 1. In each scenario, the capped bars represent the 95 per cent confidence intervals around the expected values. The solid bars represent a scenario in which a state has a defensive alliance with a democratic state. The dotted bars represent a state with no defensive alliance and the dashed bars indicate a state with a non-democratic defensive alliance. In each scenario, the value of military spending begins at the sample mean and adjusts with the prediction

${ }^{62}$ It is possible to interpret the effect of binary indicators in a log-linear model, in terms of percentages, with the following equation: $\exp \left(\beta_{i}\right)-1$.

63 Nordhaus et al. 2012.

${ }_{64}$ Model 5 is also robust to the inclusion of country and year fixed effects.

65 Koyck 1954.

66 See Williams and Whitten 2012. 


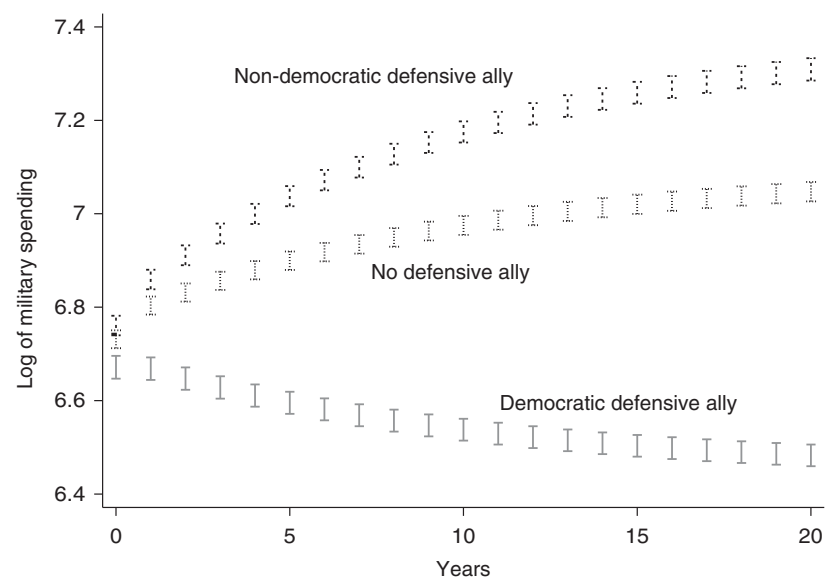

Fig. 1. Simulated long-term effect of alliance types on the log of military expenditure over twenty years based on the estimates of Model 5

Note: capped bars represent the 95 per cent confidence intervals around the expected value. Simulations are based on 10,000 draws of the coefficient and variance-covariance matrices.

of each scenario from the previous year, independently of the other scenarios. We also set the war variables to zero and hold the remaining covariates at their sample means in each simulation.

The significance of the short-term effect is apparent in that the confidence intervals around the democratic defensive ally scenario does not overlap with the confidence intervals produced by the other two scenarios. Future estimates of the democratic and non-democratic alliance scenarios exceed the confidence intervals of their initial value, thereby indicating the significance of each LTE and providing further support for our two hypotheses. States with a democratic defensive ally see a decrease in their military spending over time. States with a nondemocratic ally see a small positive increase in spending over time. More importantly, the figure indicates that the long-term difference between the scenarios is several times larger than the initial effects. After twenty years, additional calculations reveal that a state with a democratic ally spends 39 per cent less on its military than states that have no alliances. ${ }^{67}$ This effect is considerable and supports our argument that external arming allows states to forgo internal arming when their allies are reliable (that is, democratic).

Because of concerns regarding bias in the lagged dependent variable, we also present simulations based on the estimates in which we instrumented the lagged dependent variable (Model 5) in Figure 2. Again, the LTE of a democratic alliance has a significant effect over time. However, since the value of the lagged dependent variable is much smaller, the size of the LTE is smaller and plays out more quickly. Overall, the simulations used to produce Figure 2 indicate that states with democratic allies spend about 55 per cent less on their military than those with non-democratic allies after ten years.

\section{Further Tests}

Our analysis demonstrates that without estimating the effect of democratic and non-democratic defensive alliances separately, evidence of both the short- and long-run trade-offs between arms

67 This number was attained by exponentiating the logged expected values for the twentieth year and calculating the percent change difference between the two scenarios. 


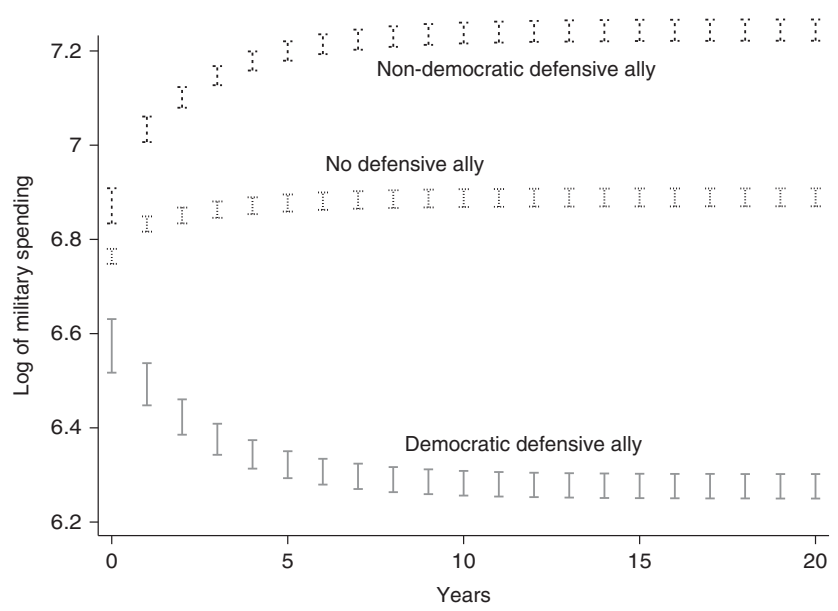

Fig. 2. Simulated long-term effect of alliance types on the log of military expenditure over twenty years based on the estimates of Model 5

Note: capped bars represent the 95 per cent confidence intervals around the expected value. Simulations are based on 10,000 draws of the coefficient and variance-covariance matrices.

and alliances is obscured by the positive relationship between non-democratic alliances and military spending. A shortcoming of the above analysis, however, is that we have treated all democratic and non-democratic allies equally and ignored the fact that some alliances matter more than others. Consequently, our results may be a function of membership in large multilateral alliances or alliances with major powers. We address these and similar concerns in models presented in Table 3 .

First, it is possible that our results are a function of membership in specific alliances unique to the time period. Our finding that democratic alliances are associated with less military spending may be a product of membership in the North Atlantic Treaty Organization (NATO), which counts the world's superpower and other powerful democratic states among its members. Furthermore, evidence suggests that NATO members often free-ride on the alliance commitments of others. ${ }^{68}$ Similarly, our puzzling result that non-democratic alliances correlate with higher military spending may be driven by specific alliances. Given the time period of our analysis, it is possible that this result could be the driven by the Cold War behavior of communist states in the Warsaw Pact. This was a large multilateral alliance of nondemocratic states that also maintained relatively high levels of military expenditures. Further, the budgetary politics of non-Soviet members of the Warsaw Treaty Organization were likely influenced by coercion, if not direct control, from the USSR. ${ }^{69}$ We test for both possibilities in Model 6 by including separate binary indicators of membership in NATO and the Warsaw Pact. As reported, the coefficient of democratic defense alliance remains significant when controlling for membership in these alliances. ${ }^{70}$ The coefficient for non-democratic defense allies is no

68 Plumper and Neumayer 2015.

69 We thank an anonymous reviewer for bringing this to our attention.

70 Our results are also robust to models that exclude NATO and Warsaw Pact membership in our construction

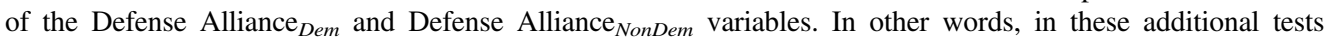
reported in the Appendix, we do not code a democratic alliance if a state only belongs to NATO but do code a democratic alliance if a state belongs to NATO and has a separate alliance with another democratic state. 


\begin{tabular}{|c|c|c|c|c|c|c|c|}
\hline & $\begin{array}{c}(6) \\
\text { NATO/Warsaw }\end{array}$ & $\begin{array}{c}(7) \\
\text { US/USSR }\end{array}$ & $\begin{array}{c}(8) \\
\text { Major power }\end{array}$ & $\begin{array}{c}(9) \\
\text { Multilateral }\end{array}$ & $\begin{array}{c}(10) \\
\text { Ally exp. }\end{array}$ & $\begin{array}{c}(11) \\
\text { Pre-ally }\end{array}$ & $\begin{array}{c}(12) \\
\text { Neighborhood }\end{array}$ \\
\hline \multirow[t]{2}{*}{$\ln (\text { Military Exp. })_{t-1}$} & $0.898 *$ & $0.899 *$ & $0.902 *$ & $0.903 *$ & $0.902 *$ & $0.903 *$ & $0.903 *$ \\
\hline & $(0.01)$ & $(0.01)$ & $(0.01)$ & $(0.01)$ & $(0.01)$ & $(0.0100)$ & $(0.01) 00$ \\
\hline \multirow[t]{2}{*}{ Polity } & $-0.003^{*}$ & $-0.002 *$ & $-0.003^{*}$ & $-0.003 *$ & $-0.002 *$ & $-0.003^{*}$ & $-0.002 *$ \\
\hline & $(0.0007)$ & $(0.0007)$ & $(0.0007)$ & $(0.0007)$ & $(0.0007)$ & $(0.0007)$ & $(0.0007)$ \\
\hline \multirow[t]{2}{*}{ Defense Alliance $_{\text {Dem }}$} & $-0.0542 *$ & $-0.0321 *$ & $-0.0679 *$ & $-0.0551^{*}$ & & $-0.0528 *$ & $-0.0556 *$ \\
\hline & $(0.0108)$ & $(0.0152)$ & $(0.0133)$ & $(0.0111)$ & & $(0.0105)$ & $(0.0102)$ \\
\hline \multirow{2}{*}{ Defense Alliance $_{\text {NonDem }}$} & 0.0197 & $0.0198 *$ & $0.0215^{*}$ & 0.0171 & & $0.0260 *$ & $0.0369 *$ \\
\hline & $(0.0101)$ & $(0.0100)$ & $(0.00979)$ & $(0.0160)$ & & $(0.00977)$ & $(0.0105)$ \\
\hline \multirow[t]{2}{*}{ ln(Rival Mil. Exp.) } & $0.00738 *$ & $0.00741 *$ & $0.00665 *$ & $0.00651 *$ & $0.00653 *$ & $0.00643 *$ & $0.00587 *$ \\
\hline & $(0.00137)$ & $(0.00137)$ & $(0.00129)$ & $(0.00128)$ & $(0.00129)$ & $(0.00129)$ & $(0.00128)$ \\
\hline \multirow[t]{2}{*}{ Interstate War } & $0.100^{*}$ & $0.103^{*}$ & $0.102 *$ & $0.100 *$ & $0.0998 *$ & $0.100 *$ & $0.0980 *$ \\
\hline & $(0.0230)$ & $(0.0231)$ & $(0.0230)$ & $(0.0230)$ & $(0.0230)$ & $(0.0230)$ & $(0.0230)$ \\
\hline \multirow{2}{*}{ Civil War } & $0.0405 *$ & $0.0413^{*}$ & $0.0401 *$ & $0.0378 *$ & $0.0387 *$ & $0.0377 *$ & $0.0366^{*}$ \\
\hline & $(0.0182)$ & $(0.0182)$ & $(0.0182)$ & $(0.0181)$ & $(0.0181)$ & $(0.0181)$ & $(0.0182)$ \\
\hline \multirow[t]{2}{*}{$\ln (\mathrm{GDP})$} & $0.0972 *$ & $0.0991 *$ & $0.0959 *$ & $0.0965 *$ & $0.0973 *$ & $0.0964 *$ & $0.0989 *$ \\
\hline & $(0.0108)$ & $(0.0111)$ & $(0.0107)$ & $(0.0108)$ & $(0.0110)$ & $(0.0108)$ & $(0.0109)$ \\
\hline \multirow[t]{2}{*}{ Peacetime Coor. } & $0.0197 *$ & $0.0191 *$ & $0.0230 *$ & $0.0246 *$ & $0.0227 *$ & $0.0245 *$ & $0.0217 *$ \\
\hline & $(0.0056)$ & $(0.0056)$ & $(0.0056)$ & $(0.0057)$ & $(0.0057)$ & $(0.0057)$ & $(0.0056)$ \\
\hline \multirow[t]{2}{*}{ NATO } & $0.0682 *$ & & & & & & \\
\hline & $(0.0139)$ & & & & & & \\
\hline \multirow[t]{2}{*}{ Warsaw Pact } & $0.0645^{*}$ & & & & & & \\
\hline & $(0.0271)$ & & & & & & \\
\hline \multirow[t]{2}{*}{ US Ally } & & -0.0167 & & & & & \\
\hline & & $(0.0156)$ & & & & & \\
\hline USSR Ally & & $\begin{array}{c}0.0736 * \\
(0.0226)\end{array}$ & & & & & \\
\hline
\end{tabular}


Major Power Ally

Multilateral Alliance

$\ln (\text { Ally Exp. })_{D e m}$

$\ln (\text { Ally Exp. })_{\text {Nondem }}$

Pre Alliance ${ }_{\text {Dem }}$

Pre Alliance ${ }_{\text {NonDem }}$

Neighborhood Polity

\section{Constant}

AR1

Observations

$R^{2}$

Note: panel-corrected standard errors in parentheses. ${ }^{*} \mathrm{p}<0.05$.
0.0265

(0.0141)

$$
0.0123
$$

(0.0202)

$-0.00388^{*}$

(0.000894)

$0.00267 *$

(0.000967)

$-0.00229$

(0.0210)

0.00472

(0.0149)

$-0.00948^{*}$

$(0.00347)$

$-0.384 *$

0.0590

Yes

5,889

0.98 
longer significant. We take this finding as evidence that the Warsaw Pact partially explains the relationship between non-democratic defense pacts and higher military spending.

For similar reasons, a defense pact with the United States after World War II or a defense pact with the USSR during the Cold War outside of these two notable alliances may also influence our results. As such, Model 7 includes binary indicators of defensive alliance commitments with the United States and Soviet Union. Next we examine whether the support for our hypotheses is a function of an alliance with a major power, as major powers are disproportionally democratic in the period under investigation. In each model, the coefficient of a democratic alliance is negative and significant. Together, we interpret these findings as evidence that our initial results are not simply a function of an alliance commitment with a superpower or major power for reasons that diverge from states' motivations to substitute arms and alliances. Most importantly, the relationship between democratic defense pacts and military expenditure does not appear to be driven solely by agreements with the United States or other powerful democratic states.

Democracies are more likely than non-democracies to form multilateral alliances, and often do so with other democracies. ${ }^{71}$ Thus we risk the possibility that our results are picking up the effect of multilateral alliances on military expenditure. To demonstrate this is not the case, we estimate our basic model adding a binary indicator of multilateral alliance membership. The results, reported in Model 9, demonstrate that our key finding does not appear to be driven by this alternative explanation. Further, being in a non-democratic defense pact is no longer statistically significant when controlling for multilateral alliances. This further suggests that this finding is a product of membership in the Warsaw Pact and, potentially, similar multilateral alliances among non-democratic states.

Next, our choice to use binary indicators of defense pact agreement is motivated by theoretical concerns that it is the quality of alliances that matters, rather than the quantity of power provided by alliance agreements. However, this approach does ignore the number of defensive alliances a partner holds, as well as the combined power that a state's democratic and non-democratic allies can contribute in the event of conflict. We address this issue by substituting the binary indicators of defense pacts with a variable capturing the log sum of military spending of a state's democratic allies and a variable capturing the log sum of military spending of a state's non-democratic allies. Consistent with the previous models, as reported in Model 10, the logged sum of democratic allies' military spending is significant and negatively correlated with expenditures, while the logged sum of non-democratic allies' military spending is positive and significant. We report in the Appendix that this finding holds in specifications similar to those reported in Model 3 and in separate specifications that exclude US and NATO spending from the logged sums of democratic defense pact military spending, and also when we control separately for US and NATO military spending.

We now consider three alternative explanations for our core finding. Model 11 addresses the possibility that the negative changes in military expenditure associated with democratic defense pacts are driven by states' efforts to build up their military strength before forming alliances. States may increase their military expenditure prior to defense pact formation to enhance their attractiveness to the most desirable (democratic) potential allies or, as is in the case of NATO, to satisfy certain capability levels or components required for alliance admittance. We address this concern by including two binary variables indicating if a state joins an alliance in the subsequent two years with a democratic or non-democratic state. ${ }^{72}$ The stability of estimates in

${ }^{71}$ Gibler and Wolford 2006.

72 The result stands with leads of 3,4 and 5 years. 
Model 11 and the insignificance of the pre-alliance variables suggest that our previous results are not driven by pre-alliance build-ups.

Lastly, Model 12 addresses concerns that both military expenditure and alliance ties are a product of proximity and that democratic neighbors tend to be more peaceful. Consequently, states surrounded by democratic states may have fewer threats, as well as a greater opportunity to form alliances with democracies. While country-fixed effects partially address this concern, regime type is still dynamic (albeit slow moving). As such, Model 11 includes a spatially weighted measure of neighborhood regime type. ${ }^{73}$ We find that more democratic neighborhoods are associated with lower military spending. However, the coefficient of Defensive Alliance $_{\text {Dem }}$ remains negative, statistically significant and of similar magnitude to the previous models.

\section{Accounting for Endogeneity}

A majority of the evidence brought to bear on the internal-external arming debate estimates the influence of various factors on the probability of alliance formation. ${ }^{74}$ This provides good reason to think that defense pacts and military spending are co-determinous processes.

Further, as we discussed above, it is likely that democratic and non-democratic states sort themselves into different alliances. Without accounting for this endogeneity and selection process, the estimates of the linear models above are potentially biased. Below, we discuss our analysis to address this concern.

The first step in conducting this analysis is to specify a model with three outcomes: defense pact ties with a democracy, defense pact ties with a non-democracy, and the log of military expenditure. Again, we employ the ATOP data for our defense pact outcome variables. These binary indicators capture whether a state in the observed year is a member of a defense pact with a democracy or a non-democracy. While we are estimating defense pact ties, we inform our model with several commonly used predictors of alliance formation, many of which are also found in our models estimating military expenditure. These include regime type, rival military expenditure, interstate war occurrence and the log of GDP. Lastly, alliances tend to persist once established. To capture such temporal dependence, we include separate binary variables indicating the presence of a defense pact with a democracy or a non-democracy in the previous period.

Equipped with equations predicting defense pact formation, we now turn our attention to jointly estimating two binary outcomes and one continuous outcome in a manner that allows for an endogenous relationship. To this end, we rely on the conditional mixed-process (CMP) estimator. ${ }^{75}$ The estimator builds on a seemingly unrelated regression maximum likelihood framework and is unique in that it jointly estimates equations with different outcome types while also allowing for simultaneity. ${ }^{76}$

73 We employ an inverse distance weight on all system states. We use the following formula to calculate the spatially weighted measure:

$$
\text { Neighborhood Polity }=\frac{\sum_{i t} w_{i j t} d_{j t}}{\sum_{i t} w_{i j t}},
$$

where $d_{j t}$ is the polity score of neighborhood state $j$ at time $t$ and $w_{i j t}$ is the capital-to-capital distance between the observed state $i$ and neighborhood state $j$ at time $t$.

74 Allen and DiGiuseppe 2013; Horowitz et al. forthcoming; Kimball 2010.

75 Roodman 2011.

76 We use the CMP package for STATA. The package is widely used in the development economics literature and more recently in political science (Horowitz et al. 2011; Murdie and Peksen 2014). See Roodman (2011) and 
Here, we have one continuous variable and two binary outcomes. More precisely, we jointly estimate the following equations within a fully observed framework:

$$
\begin{gathered}
\ln \left(\text { Exp }_{\cdot i t}\right)=\beta_{0}+\gamma \ln \left(\text { Exp } \cdot \text { it }-1_{1}\right)+\beta_{1} \text { Alliance }_{\text {Dem }}+\beta_{2} \text { Alliance }_{\text {NonDem }}+\beta \text { controls }+\epsilon_{1} \\
\text { AllianceTies }_{\text {Dem }}=\theta_{0}+\theta_{1} \ln \left(\text { Exp } \cdot i t_{i t}\right)+\theta \text { Controls }+\epsilon_{2} \\
\text { AllianceTies } \text { NonDem }_{1}=\psi_{0}+\psi_{1} \ln \left(\text { Exp }_{\cdot i t}\right)+\psi \text { Controls }+\epsilon_{3}
\end{gathered}
$$

Unlike linear simultaneous estimators, the non-linearities introduced by the binary dependent variables require fewer assumptions. To achieve identification it is recommended to include one exogenous variable for each endogenous variable included. ${ }^{77}$ This is the case with our model, as the indicators of previous alliance commitments in the two alliance formation equations are not found in the military spending equation, and three variables in the military spending equation $\left(\ln (\text { Military Exp. })_{i, t-1}\right.$, Civil War and Peacetime Coordination) are absent from the defense pact equations. $^{78}$

Table 4 presents the results of the CMP model. The upper third of the table indicates that a defense pact with a non-democracy has a strong negative relationship on military spending even while accounting for endogeneity. The presence of an alliance with a democracy is associated with an approximately 4 per cent decrease in military spending. This is consistent with the findings presented above and provides confidence that our initial results in support of both hypotheses are not driven by an endogenous process. We present similar models in the Appendix in which we include yearly fixed effects and control for NATO, US and USSR alliances. In each case, the finding that defense pacts with democratic states are associated with less military spending persists.

Besides indicating that our results are robust to potential endogeneity, the CMP model offers further evidence supporting our contention that the arms vs. alliance trade-off is more salient among democratic allies. First, the bottom two sets of results in Table 4 indicate that military expenditure is negatively related to alliance ties with a democracy but not to defense pacts with a non-democracy. In other words, the lower a state's military expenditure, the more likely it is to have an alliance with a democratic state. This suggests that states that cannot (or will not) raise military expenditure are more likely to seek democratic - but not non-democratic - allies.

Next, the $\rho$ parameters indicate the correlation between the errors of each pair of equations and the degree to which unobserved factors predicting each outcome are related. By extension, this provides a useful metric to judge the degree to which these outcomes are part of a similar process. The correlation between the $\ln$ (Military Expenditures) and Defense Alliance $_{\text {Dem }}$ outcome, $\rho_{12}$, is positive and statistically significant. This suggests that the decisions to arm and to form and maintain a defensive pact with a democracy are related. $\rho_{13}$ is statistically insignificant, indicating no significant correlation between arming and alliances with nondemocracies. Hence, it appears that arming and forming an alliance with a non-democracy are largely unrelated processes. In all, this further supports our central argument.

\section{(F'note continued)}

the updated STATA help file for a more detailed explanation of the estimator. Previous versions of CMP required that the system of equations be recursive. This is no longer the case. The estimator now produces consistent estimates for fully simultaneous specifications.

77 Greene 2000, 670.

78 In the Appendix, we provide additional models in which we use Keshk et al.'s (2004) method of jointly estimating one binary and one continuous simultaneous outcome. In this analysis, we model simultaneous equations of $\log$ of military expenditure with democratic states and non-democratic states separately. The results are consistent with those presented here. 


\begin{tabular}{|c|c|c|}
\hline & $\beta$ & Std. Error \\
\hline & In(Military Expenditure) & \\
\hline $\ln (\text { Military Exp. })_{t-1}$ & $0.92 *$ & $(0.011)$ \\
\hline Polity & $-0.0020 *$ & $(0.00062)$ \\
\hline $\ln$ (Rival Mil. Exp.) & $0.0054 *$ & $(0.0013)$ \\
\hline Interstate War & $0.092 *$ & $(0.019)$ \\
\hline Civil War & 0.031 & $(0.020)$ \\
\hline $\ln (\mathrm{GDP})$ & $0.084 *$ & $(0.012)$ \\
\hline Peacetime Coordination & $0.019 *$ & $(0.0057)$ \\
\hline Defense $_{\text {Dem }}$ & $-0.066^{*}$ & $(0.013)$ \\
\hline Defense $_{\text {NonDem }}$ & $0.038 *$ & $(0.013)$ \\
\hline$\beta_{0}$ & $-0.29 *$ & $(0.055)$ \\
\hline & Defense Alliance Dem $_{\text {De }}$ & \\
\hline $\ln ($ Military Expenditure) & $-0.15 *$ & $(0.038)$ \\
\hline Polity & $0.024 *$ & $(0.0047)$ \\
\hline $\ln$ (Rival Mil. Exp.) & 0.00092 & $(0.0083)$ \\
\hline Interstate War & $0.49 *$ & $(0.20)$ \\
\hline $\ln (\mathrm{GDP})$ & $0.17 *$ & $(0.046)$ \\
\hline Defense $_{\text {Dem }_{t-1}}$ & $3.51 *$ & $(0.073)$ \\
\hline Defense $_{\text {NonDem }_{t-1}}$ & $0.64 *$ & $(0.068)$ \\
\hline$\theta_{0}$ & $-2.95 *$ & $(0.27)$ \\
\hline & Defense Alliance $_{\text {NonDem }}$ & \\
\hline $\ln ($ Military Expenditure) & 0.085 & $(0.046)$ \\
\hline Polity & -0.0085 & $(0.0056)$ \\
\hline $\ln$ (Rival Mil. Exp.) & 0.0044 & $(0.0097)$ \\
\hline Interstate War & 0.048 & $(0.14)$ \\
\hline $\ln (\mathrm{GDP})$ & $-0.13 *$ & $(0.050)$ \\
\hline Defense $_{\text {Dem }}$ & $0.34 *$ & $(0.088)$ \\
\hline Defense $_{\text {NonDem }_{t-1}}$ & $4.04 *$ & $(0.087)$ \\
\hline$\psi_{0}$ & $-1.25^{*}$ & $(0.28)$ \\
\hline$\rho_{12}$ & $0.10^{*}$ & $(0.029)$ \\
\hline$\rho_{13}$ & -0.0049 & $(0.044)$ \\
\hline$\rho_{23}$ & $0.60 *$ & $(0.13)$ \\
\hline Observations & 6,113 & \\
\hline
\end{tabular}

Note: robust standard errors in parentheses. $* \mathrm{p}<0.05$.

\section{CONCLUSION}

Arms and allies are the pillars of a state's military power. Security depends on the ability of these instruments to effectively counter direct aggression from threats. Scholars have long recognized a relationship between arms and allies. However, despite theoretical expectations of a trade-off, there is little evidence that states substitute arms and allies. This reflects a failure to distinguish reliable from unreliable allies, and demonstrates how this difference influences the armament decisions of alliance members. We have argued that the costs imposed on democratic states for failing to uphold an alliance agreement, by reducing the probability of abandonment, provide their allies with the ability to reduce arms. Our empirical findings strongly support this argument during the period for which we have data to appropriately test our argument, 1950-2001.

These findings have important implications for the study of alliances and the role of democracies in the international system. Most obviously, the findings improve our understanding of whether (and how) states substitute arms for alliances. This is important in 
and of itself, but is also relevant for the literature on burden sharing in alliances. If states doubt the commitment of their allies, then smaller allies will have fewer incentives to free-ride on the contribution of larger states. Our argument and empirical evidence are consistent with previous findings that states free-ride on the contributions of larger states in largely democratic alliances, but not in alliances consisting primarily of non-democratic states.

Of course, democratic institutions are but one of several factors that may influence conceptions of alliance reliability. Indeed, as more and more countries acquire consolidated democratic institutions, leaders might turn to other indicators to separate reliable from unreliable types. This would, in turn, negate the foreign policy benefits associated with democracy. ${ }^{79}$ Future research should consider how other variables predictive of alliance reliability - such as an ally's reputation or the political and economic ties between alliance partners - may also provide insight into the arms versus allies trade-off. If the claims of this research are sound, then such future work should reveal that the trade-off exists only when the allies are deemed reliable.

\section{REFERENCES}

Allen, Michael A., and Matthew DiGiuseppe. 2013. Tightening the Belt: Sovereign Debt and Alliance Formation. International Studies Quarterly 57 (4):647-59.

Altfeld, Michael. 1984. The Decision to Ally. Western Political Quarterly 37 (4):523-44.

Barnett, Michael N., and Jack S. Levy. 1991. Domestic Sources of Alliances and Alignment: The Case of Egypt, 1962-73. International Organization 45 (3):369-95.

Beck, Nathaniel, and Jonathan Katz. 2011. Modeling Dynamics in Time-Series-Cross-Sectional Political Economy Data. Annual Review of Political Science 14:331-52.

Bennett, Scott D. 1997. Democracy, Regime Change, and Rivalry Termination. International Interactions 22 (4):369-97.

Benson, Brett V., Adam Meirowitz, and Kristopher W. Ramsay. 2014. Inducing Deterrence Through Moral Hazard in Alliance Contracts. Journal of Conflict Resolution 58 (2):307-35.

Boef, Suzanna D., and Luke Keele. 2008. Taking Time Seriously. American Journal of Political Science 52 (1):184-200.

Bueno de Mesquita, Bruce, Alastair Smith, Randolph M. Siverson, and James D. Morrow. 2003. The Logic of Political Survival. Cambridge, MA: MIT Press.

Bueno de Mesquita, Bruce, James D. Morrow, Randolph M. Siverson, and Alastair Smith. 1999. An Institutional Explanation of the Democratic Peace. The American Political Science Review 93 (4):791-807.

Chen, Baizhu, Yi Feng, and Cyrus Masroori. 1996. Collective Action in the Middle East? A Study of Free-Ride in Defense. Journal of Peace Research 33 (3):323-39.

Clare, Joe. 2013. The Deterrent Value of Democratic Allies. International Studies Quarterly 57:545-55.

Conybeare, John A. C. 1992. A Portfolio Diversification Model of Alliances. Journal of Conflict Resolution 36 (1):53-85.

Conybeare, John A. C. 1994. Arms Versus Allies: The Capital Structure of Military Enterprise. Journal of Conflict Resolution 38 (2):215-35.

Dai, Xinyuan. 2005. Why Comply? The Domestic Constituency Mechanism. International Organization 59 (2):363-98.

Diehl, Paul F. 1994. Substitutes or Complements?: The Effects of Alliances on Military Spending in Major Power Rivalries. International Interactions 19 (3):159-76.

Fordham, Benjamin, and Paul Poast. Forthcoming. All Alliances are Multilateral: Rethinking Alliance Formation. Journal of Conflict Resolution.

79 Gartzke and Weisiger 2013. 
Fordham, Benjamin, and Thomas Walker. 2005. Kantian Liberalism, Regime Type, and Military Resource Allocation: Do Democracies Spend Less? International Studies Quarterly 4 (1):141-57.

Gartzke, Erik, and Alex Weisiger. 2013. Fading Friendships: Alliances, Affinities and the Activation of International Identities. British Journal of Political Science 43 (1):25-52.

Gartzke, Erik, and Kristian S. Gleditsch. 2004. Why Democracies May Actually be Less Reliable Allies. American Journal of Political Science 48 (4):775-95.

Gaubatz, Kurt T. 1996. Democratic States and Commitment in International Relations. International Organization 50 (1):109-39.

Gibler, Douglas. 2008. The Costs of Reneging: Reputation and Alliance Formation. Journal of Conflict Resolution 52 (3):426-54.

Gibler, Douglas, and Scott Wolford. 2006. Alliances, Then Democracy: An Examination of the Relationship Between Regime Type and Alliance Formation. Journal of Conflict Resolution 50 (1):129-53.

Goldsmith, Benjamin. 2007. Defense Effort and Institutional Theories of Democratic Peace and Victory: Why Try Harder? Security Studies 16 (2):189-222.

Greene, William H. 2000. Econometric Analysis, 4th edition, New York: Prentice-Hall.

Guzman, Andrew T. 2009. How International Law Works: A Response to Commentators. International Theory 1 (2):335-43.

Hart, Robert A.Robert A. Jr., and William Reed. 1999. Selection Effects and Dispute Escalation: Democracy and Status Quo Evaluations. International Interactions 25 (3):243-63.

Horowitz, Michael C., Erin M. Simpson, and Alan C. Stam. 2011. Domestic Institutions and Wartime Casualties. International Studies Quarterly 55 (4):909-36.

Horowitz, Michael C., Paul Poast, and Alan C. Stam. Forthcoming. Domestic Signaling of Commitment Credibility: Military Recruitment and Alliance Formation. Journal of Conflict Resolution.

Johnson, Jesse, Brett Ashley Leeds, and Ahra Wu. 2015. Capability, Credibility, and the Extended General Deterrence. International Interactions 41 (2):309-36.

Keele, Luke, and Nathan J. Kelly. 2006. Dynamic Models for Dynamic Theories: The Ins and Outs of Lagged Dependent Variables. Political Analysis 14:186-205.

Keshk, Omar, Brian M. Pollins, and Raphael Reuveny. 2004. Trade Still Follows the Flag: The Primacy of Politics in a Simultaneous Model of Interdependence and Armed Conflict. Journal of Politics 66 (4):1155-179.

Kimball, Anessa L. 2010. Political Survival, Policy Distribution, and Alliance Formation. Journal of Peace Research 47 (4):407-19.

Koremenos, Barbara, Charles Lipson, and Duncan Snidal. 2001. The Rational Design of International Institutions. International Organization 55 (4):761-99.

Koyck, Leendert M. 1954. Distributed Lags and Investment Analysis, Vol. 4. Amsterdam: North-Holland Publishing Company.

Kydd, Andrew. 2009. Reputation and Cooperation: Guzman on International Law. International Theory 1 (2):295-305.

Lai, Brian, and Dan Reiter. 2000. Democracy, Political Similarity, and International Alliances, 1816-1992. Journal of Conflict Resolution 44 (2):203-27.

Leeds, Brett Ashley. 1999. Domestic Political Institutions, Credible Commitments, and International Cooperation. American Journal of Political Science 43 (4):979-1002.

Leeds, Brett Ashley. 2003. Alliance Reliability in Times of War: Explaining State Decisions to Violate Treaties. International Organization 57 (4):801-27.

Leeds, Brett Ashley, and Burcu Savun. 2007. Terminating Alliances: Why do States Abrogate Agreements? Journal of Politics 69 (4):1118-132.

Leeds, Brett Ashley, Jeffrey M. Ritter, Sara L. Mitchell, and Andrew G. Long. 2002. Alliance Treaty Obligations and Provisions, 1815-1944. International Interactions 28 (3):237-60.

Leeds, Brett Ashley, Michaela Mattes, and Jeremy S. Vogel. 2009. Interests, Institutions, and the Reliability of International Commitments. American Journal of Political Science 53 (2): 461-76. 
Leeds, Brett Ashley, and Sezi Anac. 2005. Alliance Institutionalization and Alliance Performance. International Interactions 31 (1):183-202.

Levendusky, Matthew S., and Michael C. Horowitz. 2012. When Backing Down is the Right Decision: Partisanship, New Information, and Audience Costs. The Journal of Politics 74 (2):323-38.

Levy, Jack S., Michael K. McKoy, Paul Poast, and Geoffrey PR Wallace. 2015. Backing Out or Backing In? Commitment and Consistency in Audience Costs Theory. American Journal of Political Science 59 (4):988-1001.

Marshall, Monty G., Keith Jaggers, and Ted Gurr. 2010. Polity IV Project: Data Users Manual. Available at http://www.systemicpeace.org/inscr/p4manualv2013.pdf, accessed 18 May 2016.

Martin, Lisa L. 2000. Democratic Commitments: Legislatures and International Cooperation. Princeton, NJ: Princeton University Press.

Mattes, Michaela. 2012a. Democratic Reliability, Precommitment of Successor Governments, and the Choice of Alliance Commitment. International Organization 66 (1):153-72.

Mattes, Michaela. 2012b. Reputation, Symmetry, and Alliance Design. International Organization 66 (4):679-707.

Mattes, Michaela, Brett Ashley Leeds, and Royce Carroll. 2015. Leadership Turnover and Foreign Policy Change: Societal Interests, Domestic Institutions, and Voting in the United Nations. International Studies Quarterly 59 (2):280-90.

McGillivray, Fiona, and Alastair Smith. 2004. The Impact of Leadership Turnover on Trading Relations Between States. International Organization 58 (3):567-600.

McGillivray, Fiona, and Alastair Smith. 2008. Punishing the Prince: A Theory of Interstate Relations, Political Institutions, and Leader Change. Princeton, NJ: Princeton University Press.

Michon, Georges. 1929. The Franco-Russian Alliance, 1891-1917. Sydney: Allen \& Unwin.

Morgan, T. Clifton, and Glenn Palmer. 2006. A Theory of Foreign Policy. Princeton, NJ: Princeton University Press.

Morgenthau, Hans. 1948. Politics Among Nations. The Struggle for Power and Peace. New York: Alfred A. Knopf.

Morrow, James D. 1991. Alliances and Asymmetry: An Alternative to the Capability Aggregation Model of Alliances. American Journal of Political Science 35 (4):904-33.

Morrow, James D. 1993. Arms Versus Allies: Trade-Offs in the Search for Security. International Organization 47 (2):207-33.

Morrow, James D. 1994. Alliances, Credibility, and Peacetime Costs. Journal of Conflict Resolution 38 (2):270-97.

Most, Benjamin A., and Randolph M. Siverson. 1987. Substituting Arms and Alliances, 1870-1914: An Exploration in Comparative Foreign Policy. In New Directions in the Study of Foreign Policy, edited by C. F. Hermann, C. W. Kegley and J. Rosenau. Boston, MA: Allen and Unwin.

Murdie, Amanda, and Dursun Peksen. 2014. The Impact of Human Rights INGO Shaming on Humanitarian Intervention. Journal of Politics 76 (1):215-28.

Nordhaus, William, John R. Oneal, and Bruce Russett. 2012. The Effects of International Security Environment on National Military Expenditures: A Multi-Country Study. International Organization 66 (3):491-513.

Nordhaus, William, and James Tobin. 1972. Is Growth Obsolete? In Economic Research: Retrospect and Prospect Vol 5: Economic Growth, edited by William Nordhaus and James Tobin, 1-80. Cambridge, MA: NBER.

Olson, Mancur, and Richard Zeckhauser. 1966. An Economic Theory of Alliances. The Review of Economics and Statistics 48 (3):266-79.

Plumper, Thomas, and Eric Neumayer. 2015. Free-Riding in Alliances: Testing an Old Theory with a New Method. Conflict Management and Peace Science 32 (3):247-68.

Poast, Paul. 2012. Does Issue Linkage Work? Evidence from European Alliance Negotiations, 1860 to 1945. International Organization 66 (2):277-310.

Poast, Paul. 2013. Can Issue Linkage Improve Treaty Credibility? Buffer State Alliances as a Hard Case. Journal of Conflict Resolution 57 (5):739-64. 
Reed, William. 1997. Alliance Duration and Democracy: An Extension and Cross-Validation of 'Democratic States and Commitment in International Relations'. American Journal of Political Science 41 (3):1072-078.

Reiter, Dani, Alan Stam, and Alexander B. Downes. 2009. Another Skirmish in the Battle over Democracies and War. International Security 34 (2):194-204.

Reiter, Dani, and Alan C. Stam. 2002. Democracies at War. Princeton, NJ: Princeton University Press.

Roodman, Dani. 2011. Estimating Fully Observed Recursive Mixed-Process Models with Cmp. Stata Journal 11 (3):159-206.

Schultz, Kenneth A. 2001. Democracy and Coercive Diplomacy, Vol. 76. Cambridge: Cambridge University Press.

Schultz, Kenneth A., and Barry Weingast. 2003. The Democratic Advantage: The Institutional Sources of International Competition. International Organization 57 (1):3-42.

Smith, Alastair. 1998. International Crises and Domestic Politics. American Political Science Review $92(3): 623-38$.

Snyder, Glenn H. 1984. The Security Dilemma in Alliance Politics. World Politics 36 (4):461-95.

Sorokin, Gerald L. 1994. Arms, Alliances, and Security Tradeoffs in Enduring Rivalries. International Studies Quarterly 38:421-46.

Thompson, William R. 2001. Identifying Rivals and Rivalries in World Politics. International Studies Quarterly 45 (4):557-86.

Weeks, Jessica. 2008. Autocratic Audience Costs: Regime Type and Signaling Resolve. International Organization 62 (1):35-64.

Williams, Laron K., and Guy D. Whitten. 2012. But Wait, There's More! Maximizing Substantive Inferences from TSCS Models. Journal of Politics 74 (3):685-93. 